\title{
Assessment of Water Quality and Sources of Pollution in Downstream of Ukai, Tapi River (Gujarat)
}

\author{
MONIKA DUBEY* and N. C. UJJANIA \\ Department of Aquatic Biology, Veer Narmad South Gujarat University, \\ Surat, Gujarat-395 007, India.
}

http://dx.doi.org/10.12944/CWE.10.1.45

(Received: January 19, 2015; Accepted: March 25, 2015)

\begin{abstract}
ABSTRCT
In the present paper an attempt has been made to study of physico-chemical parameters of downstream in Ukai, Tapi River (Gujarat). For this study the water samples were collected at monthly interval during December 2012 to November 2013 and important water quality parameters were analyzed. Study revealed that temperature, $\mathrm{pH}$, conductivity, dissolved oxygen, chemical oxygen demand, nitrate-n, total hardness, fluoride, chloride, total alkalinity and sodium were within the permissible limits whereas turbidity, biological oxygen demand, nitrite-n ammonia, phosphate and potassium were beyond the permissible limits of state, national and international authorities like GPCB, CPCB WHO and USEPA. These result depicted that water body was polluted in the form of nutrient enrichment which is due to agricultural activities and its runoff in and around catchment area of downstream.
\end{abstract}

Key words: Downstream, Ukai, Tapi River, Water quality and Pollution sources.

\section{INTRODUCTION}

The quality of water is a sensitive issue and it is affected by natural as well as anthropogenic processes. Increasing consumption and natural processes such as changes in precipitation inputs, erosion and weathering of crustal materials degrade surface water and impair their uses for drinking, industrial, agricultural and other purposes ${ }^{1}$. The river water is contributed directly or indirectly for human welfare and aquatic ecosystem ${ }^{2}$ it is highly vulnerable to pollution and now reached to point of crisis due to unplanned urbanization and rapid growth of industrialization. Therefore, it is important to assess the water quality and monitor the water pollution in rivers ${ }^{3}$ which help to control and conserve the aquatic resources. The water quality parameters were studied in Cauvery river (Karnataka) ${ }^{4}$, river Devaha (Uttara Pradesh) ${ }^{5}$, Chambal river (Rajasthan) ${ }^{6}$, Arasalar river (Tamil Nadu) ${ }^{7}$, Kolong river (Assam) ${ }^{8}$, Satluj river (Punjab) ${ }^{9}$, Yamuna river ${ }^{10}$ and in Tapi river ${ }^{11}$ and reported the pollution status. The objective of the present study is to assessment of the water quality and source of pollution in downstream of Ukai, Tapi River (Gujarat).

\section{MATHODOLOGY}

\section{Study area}

This study was carried out at downstream of Ukai, Tapi River (Fig. 1) which is situated on $21^{\circ}$ 162. 93 N Latitude and $73^{\circ} 212.553$ E Longitude on the southern bank of Tapi River, which is about 90 $\mathrm{km}$ from Surat city in the southern region of Gujarat State.

\section{Sample analysis}

The water samples were collected from downstream of Ukai, Tapi River (Fig. 1) during December 2012 to November 2013 and these water samples were subjected to filter for analysis. Although, water quality parameters including temperature, $\mathrm{pH}$ and dissolved oxygen were analysed in situ whereas for remaining parameters 
(turbidity, conductivity, BOD, COD, nitrate-N, nitrite- $\mathrm{N}$, ammonia, total hardness, fluoride, chloride, total alkalinity, phosphate, sodium and potassium) water samples were preserved and transported to Research Laboratory, Department of Aquatic Biology, Veer Narmad South Gujarat University, Surat. For the preservation and analysis of the water samples the standard methods ${ }^{12,13}$ were followed.

\section{RESULT AND DISCUSSION}

Water quality provide the primary assessment of the pollution status and it can be determined through assessment of water quality parameters. The results of present study on water quality parameters are described in table 1 .

Temperature may less important in pure water because of the wide range of temperature tolerance in aquatic life while in polluted water it can effects on dissolution of gases and biological process in aquatic ecosystem. In present study, it was minimum $18.000{ }^{\circ} \mathrm{C}$ during January and maximum $25.000{ }^{\circ} \mathrm{C}$ during June while it was average $21.417 \pm 0.633^{\circ} \mathrm{C}$ during the study and it was very low than the maximum permissible limit of $\mathrm{WHO}^{15}$. The river temperature generally depends on the season, geographic location, sampling time and effluents entering the stream ${ }^{11,14}$.

Turbidity of water is caused by suspended material such as sand, silt, clay, phytoplankton, microorganism or organic material which influences the light penetration. In downstream of Ukai of Tapi River turbidity was observed (15.000 - 41.500 NTU) with average $23.842 \pm 2.380$ NTU. These results were compared with maximum prescribed limits (10 NTU) of $\mathrm{WHO}^{15}$ and found significantly high that indicate of presence of pollution in studied area ${ }^{10}$.

$\mathrm{pH}$ is an important factor that determines the suitability of water for various purposes. In the present study, it was found faintly alkaline (7.700 8.610) with average value $8.269 \pm 0.078$ was low than maximum permissible limit of $\mathrm{WHO}^{15}$. Similar finding describe that fluctuation in $\mathrm{pH}$ due to microbial activity and increase in primary productivity ${ }^{16}$.

Conductivity is a measure of the ability to carry an electric current of an aqueous solution. High values of electrical conductance are the products of decomposition and mineralization of organic materials ${ }^{17}$. In the present investigation it was range $(0.200-0.800 \mathrm{~ms})$ with the average value $(0.292 \pm 0.050) \mathrm{ms}$ was comparatively low maximum permissible limit of $\mathrm{WHO}^{15}$. The results of present investigation were also verified from the results of Cauvery river (Karnataka) 4 .

Dissolved oxygen (DO) is one of the most important water quality factors of aquatic environment health and its depletion is directly affects the river ecosystem. During the present investigation it fluctuated from 1.20 to $7.20 \mathrm{mg} / \mathrm{l}$ with the average value of $4.950 \pm 0.494$ which were comparatively low than maximum prescribed limits

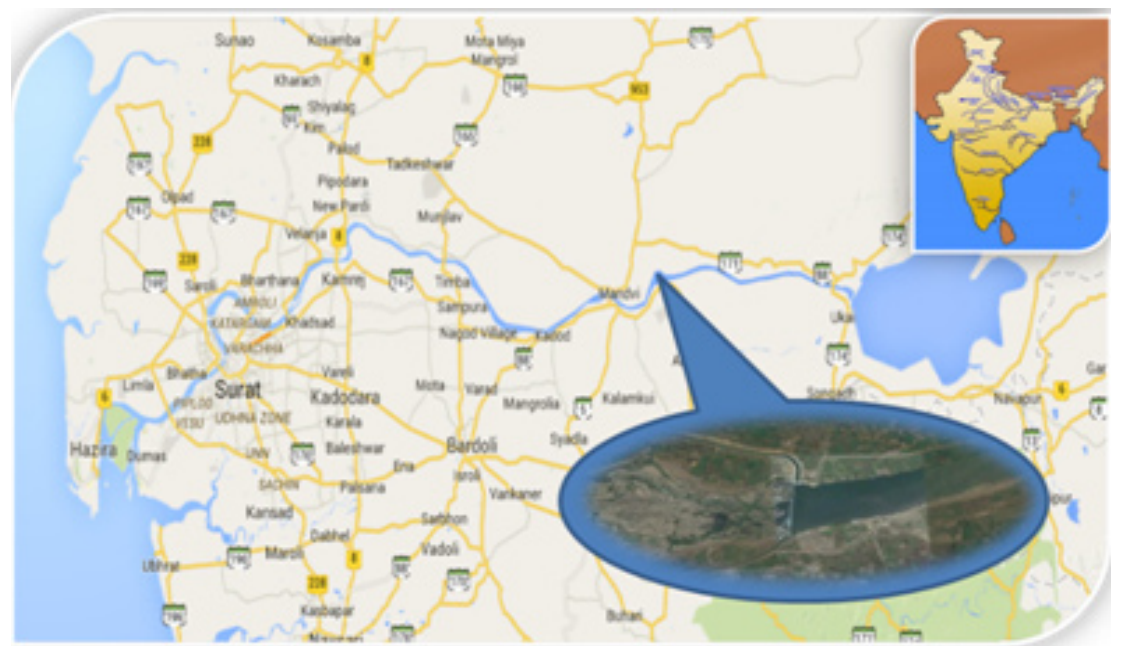

Fig. 1: Map of study area 
of $\mathrm{WHO}^{15}$. The natural turbulence and higher primary productivity which produces $\mathrm{O}_{2}$ by photosynthesis and active utilization in bacterial decomposition of organic matter ${ }^{18}$.

Biological oxygen demand (BOD) is the measurement of oxygen in water which required by the aerobic organisms. Biodegradation of organic matters exerts oxygen tension in the water and increases the biochemical oxygen demand ${ }^{17}$. The BOD was ranged 2.00 to $7.20 \mathrm{mg} / \mathrm{l}$ with the mean value $5.450 \pm 0.389 \mathrm{mg} / \mathrm{l}$ was observed in present study. The results of current study were compared to maximum permissible limits $(2.000 \mathrm{mg} / \mathrm{l})$ of $\mathrm{CPCB}^{19}$ and found high which is sign of pollution in aquatic ecosystem ${ }^{9}$.

Chemical oxygen demand (COD) is used to measure the amount of organic compounds in water and it is used as indicator of pollution in surface water ${ }^{20,21}$. The low value $(16.000 \mathrm{mg} / \mathrm{l})$ of COD noted in the Month of December and high value (232.000 $\mathrm{mg} / \mathrm{l}$ ) in September which show the variation in COD throughout the study period and the average value of COD was $79.500 \pm 20.791 \mathrm{mg} / \mathrm{l}$ which was very than limits of $\mathrm{GPCB}^{25}$ The of present investigation was evidenced in Kolong river $^{8}$.

Nitrate- $\mathrm{N}$ is an essential plant nutrient and also a good indicator of contamination by natural and human activities. It was observed 0.019 to $1.360 \mathrm{mg} / \mathrm{l}$ with mean value of $0.529 \pm 0.146 \mathrm{mg} / \mathrm{l}$ were observed comparatively low than the limits of USEPA ${ }^{26}$ and similar finding were also reported Ganga river (Ghazipur) ${ }^{22}$.

Nitrite- $\mathrm{N}$ is the intermediate in the conversion of ammonia in to nitrates through the process of nitrification and de-nitrification by bacteria. The result shows that nitrite contents were varied from 0.00 to $0.932 \mathrm{mg} / \mathrm{l}$ with average value $0.330 \pm 0.095 \mathrm{mg} / \mathrm{l}$ were observed comparatively low than the limits of USEPA $^{26}$ and result were supported by the study conducted in Moirang rivar $^{23}$.

Ammonia is produced by ammonification of organic matter. The occurrence of ammonia in the waters can be accepted as the chemical evidence of organic pollution ${ }^{12}$. The range of ammonia was observed $0.00-1.676 \mathrm{mg} / \mathrm{l}$ with average $0.611 \pm 0.129$

Table 1: Water quality parameters at downstream of Ukai, Tapi River

\begin{tabular}{ccccccc}
\hline S.N. & Parameters & Units & MPL & Minimum & Maximum & Mean \pm SE \\
\hline 1. & Temperature & ${ }^{\circ} \mathrm{C}$ & $35^{15}$ & 18.000 & 25.000 & $21.417 \pm 0.633$ \\
2. & Turbidity & $\mathrm{NTU}$ & $10^{15}$ & 15.000 & 41.500 & $23.842 \pm 2.380$ \\
3. & $\mathrm{pH}$ & & $8.5^{15}$ & 7.700 & 8.610 & $8.269 \pm 0.078$ \\
4. & Conductivity & $\mathrm{ms}$ & $1^{15}$ & 0.200 & 0.800 & $0.292 \pm 0.050$ \\
5. & Dissolve Oxygen & $\mathrm{mg} / \mathrm{l}$ & $7^{15}$ & 1.200 & 7.200 & $4.950 \pm 0.494$ \\
6. & BOD & $\mathrm{mg} / \mathrm{l}$ & $2^{19}$ & 2.000 & 7.200 & $5.450 \pm 0.389$ \\
7. & COD & $\mathrm{mg} / \mathrm{l}$ & $250^{26}$ & 16.000 & 232.000 & $79.500 \pm 20.791$ \\
8. & Nitrate-n & $\mathrm{mg} / \mathrm{l}$ & $9^{27}$ & 0.019 & 1.360 & $0.529 \pm 0.146$ \\
9. & Nitrite-n & $\mathrm{mg} / \mathrm{l}$ & $0.3^{27}$ & 0.000 & 0.932 & $0.330 \pm 0.095$ \\
10. & Ammonia & $\mathrm{mg} / \mathrm{l}$ & $0.1^{15}$ & 0.000 & 1.676 & $0.611 \pm 0.129$ \\
11. & Total Hardness & $\mathrm{mg} / \mathrm{l}$ & $500^{15}$ & 100.000 & 202.000 & $137.667 \pm 10.562$ \\
12. & Fluoride & $\mathrm{mg} / \mathrm{l}$ & $1.5^{15}$ & 0.010 & 0.030 & $0.019 \pm 0.002$ \\
13. & Chloride & $\mathrm{mg} / \mathrm{l}$ & $250^{15}$ & 22.999 & 64.998 & $36.082 \pm 4.040$ \\
14. & Total alkalinity & $\mathrm{mg} / \mathrm{l}$ & $600^{15}$ & 28.000 & 112.000 & $77.667 \pm 5.757$ \\
15. & Phosphate & $\mathrm{mg} / \mathrm{l}$ & $0.1^{15}$ & 0.000 & 0.966 & $0.674 \pm 0.075$ \\
16. & Sodium & $\mathrm{mg} / \mathrm{l}$ & $200^{15}$ & 8.800 & 50.000 & $20.588 \pm 3.476$ \\
17. & Potassium & $\mathrm{mg} / \mathrm{l}$ & $50^{15}$ & 39.000 & 98.000 & $56.500 \pm 5.171$ \\
\hline
\end{tabular}

$\mathrm{MPL}=$ maximum permissible limits, $\mathrm{SE}=$ standard error, $15=\mathrm{WHO}, 19=\mathrm{CPCB}$ and $26=\mathrm{GPCB}$, $27=$ USEPA 
$\mathrm{mg} / \mathrm{l}$ which is comparatively high than the MPL $(0.1$ $\mathrm{mg} / \mathrm{l})$ of $\mathrm{CPCB}^{15}$ and results were supported by Annalakshmi and Amsath ${ }^{7}$.

Total hardness of water is an important consideration for suitability of water for domestic and industrial uses. In the present study, the mean value of total hardness was $137.667 \pm 10.562 \mathrm{mg} / \mathrm{l}$ and it was minimum (100.00 $\mathrm{mg} / \mathrm{l})$ during May due to due to reduced inflow and higher evaporation while it was maximum $(202.00 \mathrm{mg} / \mathrm{l})$ during the month of August that may be due to increasing inflow and dilution at rainy season ${ }^{11}$.

Fluoride concentration is directly not indicating the pollution while human health and aquatic life is adversely affected by the presence of it. In the present investigation fluoride concentrate was minimum $(0.01 \mathrm{mg} / \mathrm{l})$ in July and maximum $0.03 \mathrm{mg} / \mathrm{l}$ was in January with average value of $0.019 \pm 0.002$ $\mathrm{mg} / \mathrm{l}$. which is within the permissible limit $1.5 \mathrm{mg} / \mathrm{l}$ of $\mathrm{WHO}^{15}$.

Chlorides occur naturally in all waters and its high concentration considered as the indicator of pollution which troublesome in irrigation water and harmful to aquatic life ${ }^{24}$. In present observation chloride content was fluctuated from 22.999 to $64.998 \mathrm{mg} / \mathrm{l}$ with the mean value of $36.082 \pm 4.040$ $\mathrm{mg} / \mathrm{l}$ which was significantly very low than limits of $\mathrm{WHO}^{15}$ and results were referred by the findings of Chambal river ${ }^{6}$.

Total Alkalinity itself not harmful for human beings ${ }^{12}$ moreover the value of alkalinity provides idea of natural salts present in wate ${ }^{25}$. In this study period minimum $(28.000 \mathrm{mg} / \mathrm{l})$ were recorded during September and maximum $(112.000 \mathrm{mg} / \mathrm{l})$ in June with the mean value $77.667 \pm 5.757 \mathrm{mg} / \mathrm{l}$ and comparatively it was not exceed the MPL of the $\mathrm{WHO}^{15}$.

Phosphate occurs most commonly either as orthophosphates or as polyphosphates.
Orthophosphate is form that immediately available to aquatic biota. The result shows that it was ranged from 0.000 to $0.966 \mathrm{mg} / \mathrm{l}$ and the average value was $0.674 \pm 0.075 \mathrm{mg} / \mathrm{l}$ during the study which is significantly high than recommendations of $\mathrm{WHO}^{15}$. It might be due to over use of fertilizer in agricultural field as described in Cauvery river ${ }^{4}$.

Sodium and potassium are the most important minerals occurring naturally. In present study, sodium and potassium concentration was varied from 8.80 to $50.00 \mathrm{mg} / \mathrm{l}$ and $39.00-98.00$ $\mathrm{mg} / \mathrm{l}$ respectively. The average value of sodium $(20.588 \pm 3.476 \mathrm{mg} / \mathrm{l})$ and potassium $(56.500 \pm 5.171$ $\mathrm{mg} / \mathrm{l})$ were also calculated. The potassium contents were found comparatively high than the maximum permissible limits $(50.00 \mathrm{mg} / \mathrm{l})$ of $\mathrm{WHO}^{15}$ and results was verified from the findings of river Devaha $(\mathrm{UP})^{5}$.

\section{CONCLUSION}

The present study conclude that physicochemical parameters temperature, $\mathrm{pH}$, conductivity, dissolved oxygen, chemical oxygen demand, nitrate-n, total hardness, fluoride, chloride, total alkalinity and sodium were within the permissible limits whereas turbidity, biological oxygen demand, nitrite-n ammonia, phosphate and potassium were beyond the permissible limits of state, national and international authorities like Gujarat Pollution Control Board, Central Pollution Control Board, World Health Organisation and United States Environmental Protection Agency.

The result revealed that water of downstream of Ukai, Tapi River is polluted due to presence of plant nutrient like $\mathrm{N}, \mathrm{P}$ and $\mathrm{K}$ that might be accumulated from agricultural activities and its runoff in and around catchment area of downstream of Ukai, Tapi River.

\section{REFERENCE}

1. Jarvie H. P., Whitton B. A. and Neal C., Sci. Total Environ., 210-211,79-109 (1998).

2. Costanza R., Darge R., Degroot R., Farber
S., Grasso M. and Hannon, B., Nat., 387, 253-260 (1997).

3. Simeonov V., Stratis J. A., Samara C., 
Zachariadis G., Voutsa D. and Anthemidis A. Water Res., 37, 4119-4124 (2003).

4. Venkatesharaju K., Ravikumar P., Somashekar R. K. and Prakash K. L., J. Sci. Eng. Tech., 6, 50-59 (2010).

5. Chandra A. and Saxena P.N., Orient. J. Chem., 27, 1193-1198 (2011).

6. Gupta N., Nafees S.M., Jain M.K. and Kalpana S., Rasayan J. Chem., 4, 295-298 (2011).

7. Annalakshmi G. and Amsath A., Intern. J. Plant, Animal Environ. Sci., 2, 214-222 (2012).

8. Khan I. I. and Hazarika A.K., The Clarion., 1, 121-129 (2012).

9. Chauhan B. S. and Sagar S.K. Biol. Forum An Inter. J., 5, 113-123 (2013).

10. Gupta N., Yadav K.K., Kumar V. and Singh D., Intern. J. Chem Tech Res., 5, 528-531 (2013).

11. Dubey M. and Ujjania N.C. Inter. J. Pure Appl. Zoo., 1, 261-266 (2013).

12. Trivedy, R.K. and Goel, P.K. Chemical Biological Methods for water pollution Studies. Environment Publications Karad, India. 1-104 (1986).

13. APHA Standard methods for the examination of water and wastewater. $21^{\text {st }}$ Edn., Washington, DC (2005).

14. Ahipathi M.V. and Puttaiah E.T. Environ. Geo., 49, 1217-1222 (2006).

15. WHO, Geneva 21-25 September 1992 (1993).

16. Chetana S.A. and Somasekhar R.K. J. Environ. Poll., 4, 57-63 (1997).

17. Abida B. and Harikrishna E-J. Chem., 5, 377384 (2008).
18. Jitendra S., Agrawal D.K. and Shradha P., Intern. J. Appl. Environ. Sci., 3, 107-117 (2008).

19. CPCB, Central Pollution Control Board, New Delhi, India. (2007).

20. King J. M., Scheepers A.C.T., Fisher R.C., Reinecke M.K. and Smith L.B., River Rehabilitation: Literature Review, Case studies and Emerging Principles. WRC Report No. 1161/1/03 (2003).

21. Faith N., Water Quality Trends in the Eerste River, Western Cape, 1990- 2005.A mini thesis submitted in partial fulfillment of the requirements for the degree of Magister Scientiae, Integrated Water Resources Management in the Faculty of Natural Science, University of the Western Cape. 41 (2006).

22. Yadav R.C. and Shrivastava V.C., Ind. J. Sci. Res., 2, 41-44 (2011).

23. Kosygin L., Dhamendra H. and Gyaneshwari R., J. Environ. Biol., 28, 669-673 (2007).

24. Rajkumar S., Velmurugan P., Shanthi K., Ayyasamy P.M. and Lakshmanaperumalasamy P., Water Quality of Kodaikanal lake, Tamilnadu in Relation to Physico-Chemical and Bacteriological Characteristics, Capital Publishing Company. 339-346 (2004).

25. Gawas A.D., Lokhande P.B. and Meijawas H.A., Poll Res. 25, 109-114 (2006).

26. GPCB/CPCB CCA-SRT-613/3/9/4, Issued by GPCB Under section-25 Water Act-1974, framed under Environmental protection act (1986).

27. USEPA, Office of Water Regulations and Standards, Criteria and Standards Division, Washington, DC. Draft (1987). 